Универзитет уметности у Београду, Факултет ликовних уметности, Београд

DOI 10.5937/kultura1442243F

УДК $371.3:: 75 / 76$

159.954/.956-057.874

оригиналан научни рад

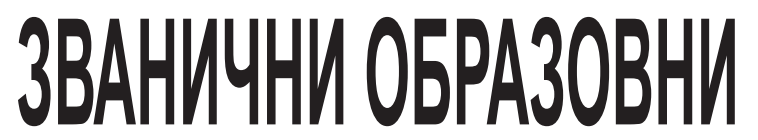
СТАНААРДИУ У ОБЛАСТИ TMKOBHE KYЛTYPE 3A KPAJ ОБАВЕЗНОГ ОБРАЗОВАНАКАКО ПРЕВАЗИПИ HEROCTATKE

Сажетак: Полазећи од општих поставки неговањ а стваралаштва деце и младих, емпиријски проверених сазнања бројних стручњака, тендениија савремене методике у домену стваралаштва, може се уочити да је опсег знања, вештина и ставова који је предвиђен Образовним стандардима за крај обавезног образовања у Србији непотпун и несистематичан када је у питағу стицање ликовне културе. Да не помиьемо чињенииу да је потпуно изостављен аспект стваралаштва, ито још у већој мери обесмишььава актуелну концеепиију Стандарда за област ликовне културе. Реперкусије овако постављених исхода су штетне за развој дечје креативности, али и иелокупне личности којој се не овај начин и формално онемогућава основно право на стваралачко изражавање и делање као базичне потребе људског бића, посебно деце у развоју. Такође, на тај начин се онемогућава и операционализачија кључних ициьева ликовног васпитања и образовања, посебно наставе ликовне културе, док се они само формализују кроз поједине исходе у Стандардима, 
без могућности њиховог систематског остваривања у актуелној васпитно-образовној пракси.

Кључне речи: стандарди у образовању, настава ликовне културе, дечје ликовно стваралаштво

\section{$У_{\text {вод }}$}

„Душа никада не мисли без слике”

Аристотел $^{1}$

Исходи су кључни елементи Стандарда који имају своје опште одреднице, али и специфичности у односу на сваку од наставних области. Исходи учења представљају операционализацију компетенција кроз различите активности у настави које су „мерљиве” и „видљиве”. У настави, специфични циљеви и исходи се одређују за сваку наставну тему/ јединицу, а у складу са компетенцијама ученика, циљевима и програмским садржајима. При њиховом одређивању могуће је ослањати се на Блумову таксономију глагола ${ }^{2}$ у којој је дефинисано шест категорија когнитивних процеса - памћење, разумевање, примена, анализа, вредновање и креираюе, као и четири димензије знања (шта се учи и испитује) по категоријама - чињенично, концептуално, прочедурално и метакогнитивно. Блумова таксономија је хијерархијска класификација процеса и продуката учења и подразумевају когнитивни домен (знање), афективни домен (ставови и емоције) и психомоторички домен (вештине). Када се говори о димензијама знања, Блум разликује четири основна типа знања и подзнања:

А. Чињенично знање - основни елементи које ученици треба да знају да би били упознати са дисциплином и могли да решавају проблеме у области:

1) Терминологија и

2) Специфични детаљи и елементи,

Б. Концептуално знање - повезаност основних елемената са ширим структурама које им омогућавају заједничко функционисање:

1 В. Панић (1998) Речник психологије стваралаштва, ЗЗУНС: Београд, 50 .

2 Anderson, L. W., Krathwohl, D. R. ,Airasian, P. W., Cruikshank, K. A., Mayer, R. E., Pintrich, P. R., Raths, J. and Wittrock, M. C. (2001) A taxonomy for learning, teaching, and assessing: A revision of Bloom's Taxonomy of Educational Objectives (Complete edition), Longman: New York. 
1) Класификације и категорије;

2) Принципи и генерализације и

3) Теорије, модели и структуре,

В. Процедурално знање - знање како нешто чинити, коришћење истраживања и критеријума, коришћење вештина, техника и метода:

1) Специфичне вештине и алгоритми;

2) Специфичне технике и методе и

3) Критеријуми за одабир одговарајућих поступака,

Г. Метакогнитивно знање - знање о когнитивним процесима, као и свесност и разумевање властитих когнитивних процеса:

1) Стратешко знање;

2) Знање о когнитивним задацима, укључујући и одговарајуће контекстуално и кондиционално знање и

3) Самоспознаја.

Оно што би требало узети као полазиште за дефинисање циљева и исхода јесу суштинска питања - Шта ученик треба да зна, разуме и уме? Шта је кључно за наставни предмет и шта је основни концепт наставног садржаја? Овакав приступ дефинисања циљева/исхода омогућава наставнику евалуацију остварености циљева, програмских садржаја и ученичких постигнућа, али даје могућност за даље унапређивање васпитно-образовног процеса и сопственог рада. Међутим, када се говори о стваралаштву, узимајући у обзир да Блумова таксономија глагола покрива само когнитивне аспекте знања, вештина и ставова, али не и перцептивни и емоционални аспект, као саставни и неизоставни део стваралачког процеса, неопходно би било дефинисати их и кроз категорије и димензије перцептивно-емоционалних процеса од којих се може поћи у одређивању циљева/исхода у домену стваралаштва, посебно наставе ликовне културе.

\section{Образовни стандарди за област}

$$
\text { ликовне културе - преглед садржаја }
$$

У Образовним стандардима за крај обавезног образовања за област ликовна култура ${ }^{3}$ усвојени су исходи који се односе на следеће области: Медији, материјали и технике визуелних уметности, Елементи, принципи и садржаји (теме,

3 Образовни стандарди за крај обавезног образовања, (2009) Република Србија, Министарство просвете и Завод за вредновање квалитета образовања и васпитања, Београд. 
мотиви, идеје...) визуелних уметности и Улога, развој и различитост визуелних уметности.

У Стандардима се користи термин „визуелна уметност” којим су обухваћени „традиционални медији ликовних и примењених уметности (цртање, сликање, вајање, графика, керамика, костимографија...), савремени медији (телевизија, филм, сви облици дизајна и дигиталне уметности...), архитектура, фолклорна уметност, уметнички занати (ткање, грнчарија, накит, радови у дрвету, папиру и другим материјалима)". Такође дефинисани су у оквиру сваке од области способности ,знања и вештине ученика преко кључних компоненти учења: основних знања, стваралачких способности и критичког мишљења."

У Стандардима следећи искази описују шта ученик/ученица зна и уме у првој области ликовни медији, материјали и технике визуелних уметности; „каже се да ученик/ ученица на: 1. основном нивоу: разликује и користи (у свом раду) основне медије, материјале и технике (цртање, сликање, вајање) визуелних уметности, изводи дводимензионалне и тродимензионалне радове и описује свој рад и радове других (нпр. исказује утисак); 2. на средњем нивоу: познаје и користи (у свом раду) основне изражајне могућности класичних и савремених медија, техника и материјала визуелних уметности и образлаже свој рад и радове других (нпр. наводи садржај, тему, карактеристике технике...); и 3. на напредном нивоу: познаје и користи различите изражајне могућности класичних и савремених медија, техника и материјала визуелне уметности и одабира адекватна средства (медиј, материјал, технику, поступак) помоћу којих ће на најбољи начин реализовати своју (одабрану) идеју.

У другој области елементи, принциии и садржаји (теме, мотиви, идеје...) визуелних уметности каже се да ученик/ ученица на 1. основном нивоу: описује свој рад и радове других (нпр. исказује утисак); 2. на средњем нивоу: одабира адекватан садржај да би представио неку идеју или концепт и образлаже свој рад и радове других (нпр. наводи садржај, тему, карактеристике технике...); 3. на напредном нивоу: одабира адекватна средства (медиј, материјал, технику, поступак) помоћу којих ће на најбољи начин реализовати своју (одабрану) идеју, изводи радове са одређеном намером, користећи основне визуелне елементе и принципе да би постигао одређени ефекат, користи тачне термине (нпр. текстура, ритам, облик...) из визуелних уметности (примерене узрасту и садржају) када образлаже свој рад и радове других и уочава међусобну повезаност елемената, принципа и садржаја на свом раду и на радовима других. 
У трећој области улога, развој и различитост визуелних уметности каже се да ученик/ученица на 1. основном нивоу: описује разлике које уочава на уметничким радовима из различитих земаља, култура и периода, зна да наведе различита занимања за која су потребна знања и вештине стечене учењем у визуелним уметностима (нпр. костимограф, дизајнер, архитекта...), познаје места и изворе где може да прошири своја знања везана за визуелне уметности (нпр. музеј, галерија, атеље, уметничка радионица...) и зна неколико примера примене визуелних уметности у свакодневном животу; 2. на средњем нивоу: лоцира одабрана уметничка дела у историјски и друштвени контекст; 3. на напредном нивоу: анализира одабрана уметничка дела у односу на време настанка и према културној припадности (описује основне карактеристике, намеру уметника...), описује потребна знања и вештине који су неопходни у занимањима везаним за визуелне уметности, користи друга места и изворе (нпр. библиотека, интернет...) да би проширио своја знања из визуелних уметности и разуме међусобну повезаност и утицај уметности и других области живота.

\section{Критичка анализа садржаја стандарда за област ликовне културе и препоруке за юихово дефинисање и допуну}

У овом сегменту биће представљен критички осврт на садржаје Стандарда за област ликовне културе у оним сегментима у којима је неопходно ревидирати их и употпунити изостављеним исходима, али и дате препоруке за њихово унапређивање. Свакако треба похвалити напор твораца овог документа да дефинишу посебне категорије и у складу са њима одреде кључне исходе. Ипак, пропусти који су идентификовани су следећи:

\section{I}

Оно што се прво уочава у Стандардима јесте да су дефинисане три категорије које се односе на медије, технике и материјале, на елементе, принципе, садржаје, као и визуелну yметност, али да недостаје један од важних сегмената, а то је стваралачки процес. Узимајући у обзир да је ликовно васпитање и образовање интердисциплинарна област која подразумева теоријске садржаје, као и процес њихове примене, исходи би морали да обухвате А) теорију у домену: уметничког наслеђа, теорије уметности и теорије форме, ликовних технологија и материјала и Б) практични рад: ликовно изражавање/стваралачки процес који укључује примену теоријских знања, вештина и ставова из претходно наведених 
теоријских области, перцепцију, доживљај и лични израз. Препорука је да се поред три наведене које би се редефинисале, уведе као посебна, четврта област, а то је стваралачки процес. Ова област се може сагледати кроз а) медији, технике и материјали - практична примена, садржаји - идеје и значењ а у односу на приказане теме и мотиве, б) ликовни језик - примена ликовних елемената и принципа компоновања и в) ликовни израз - периепџија, доживљај и креативност, из којих би били изведени исходи преко кључних компоненти учења. Дакле препорука поделе области би била следећа:

1. Ликовни медији, материјали и технике (врсте, одлике и изражајна својства)

2. Ликовни елементи и принщиии (врсте, одлике и законитости теорије форме)

3. Улога, развој и различитост визуелних уметности (визуелни медији - врсте и специфичности; развој и одлике ликовне и примењене уметности, дизајна и архитектуре епохе, уметници, дела, улога и значај ликовних уметности - друштвени, психолошки и естетски аспект и функција)

4. Стваралачки процес (медији, технике и материјали практична примена; садржаји - идеје и значења у односу на приказане теме и мотиве; ликовни језик - примена ликовних елемената и принципа компоновања; ликовни израз - перцепција, доживљај и креативност)

\section{II}

У Стандардима се користи термин „визуелна уметност” којим су обухваћени „традиционални медији ликовних и примењених уметности (цртање, сликање, вајање, графика, керамика, костимографија...), савремени медији (телевизија, филм, сви облици дизајна и дигиталне уметности...), архитектура, фолклорна уметност, уметнички занати (ткање, грнчарија, накит, радови у дрвету, папиру и другим материјалима)" . Овако постављена подела изједначава ликовну и примењену уметност као категорије визуелних уметности са фолклорном уметношћу и уметничким занатима, што је непрецизно дефинисано. Према једној од усвојених подела визуелне уметности подразумевају две кључне области 1) Ликовну уметност (сликарство, графика и вајарство), 2) Примењену уметност (примењено сликарство, примењено вајарство, конзервација и рестаурација уметничких дела, керамика, сценографија, костимографија, фотографија, илустрација...) и дизајн (графички дизајн, индустријски дизајн, дизајн ентеријера, модни дизајн, дизајн текстила, дизајн амбалаже...), као 
и архитектуру (интердисциплинарна област која поред уметности обухвата и поље наука и технологија). Наведене кључне области са својим подобластима могу користити класичне и нове медије који спадају у домен техника, материјала и начина њихове примене у овим областима (на пример, сликарство данас користи и дигиталне медије компјутерска слика као начин ликовног изражавања уметника, а да не мора нужно имати изражену произведну применљивост/функцију, што је типично за домен дизајна и примењене уметности). Потом, ткање које се наводи у Стандардима не спада у засебну уметничку дисциплину, већ спада у технику која се користи и у ликовној и у примењеној уметности (техника ткања је примењивана не само у продуктима примењене уметности, већ су израђиване и слике, као на пример, Таписерије из Бајеа, Битка код Хастингса Француска, 11. век, али и са израженом производном функцијом, која припада домену примењене уметности, као што су, на пример, ткане подне облоге теписи, прекривачи, одевни предмети у различитим епохама и културама као што је на пример исламска уметност).

\section{III}

У даљем тексту, на 61. страни у Стандардима, аутори се позивају на кључне компоненте учења: основна знања, стваралачке способности и критичко мишљење, који су коришћени при дефинисању исхода сваке од три наведене области. Међутим, анализом кључних компетенција, односно исхода који су дефинисани у Стандардима, на основу ревидиране Блумове таксономије глагола по категоријама знања, као и шест димензија когнитивних процеса, уочава се да исходи предвиђају веома мали опсег компетенција, при чему су пета и шеста категорија, које се односе на вредновање и креацију (стваралаштво) у потпуности занемарене, што је недопустиво, узимајући у обзир да је стицање ликовне културе засновано првенствено на перцепцији, доживљају и стваралачком изражавању и критичком мишљењу. У Блумовој таксономији глагола у приказаној табели су посебно обележени само они исходи који су дефинисани Стандардима у табели 1.

Као што се може видети из приказане табеле, Стандардима су обухваћене само три категорије које се односе на разумевање (разликује/лоцира, описује, препознаје), примену (изводи, користи) и анализу (анализира, одабира), док су памћење, вредновање и креирање потпуно изостављени. Полазећи од општих образовних и васпитних циљева, као и специфичних наставе ликовне културе, потребно је 
САњА ФИЛИПОВИЋ

допунити опсег постојећих исхода у Стандардима у свим димензијама когнитивних процеса, посебно вредновања и креирања, и на тај начин обухватити ученичке компетенције уз уважавање развојних могућности и потреба ученика.

\begin{tabular}{|c|c|c|c|c|c|}
\hline ПАМТИ & PAЗУМЕ & ПРИМЕЮУЈЕ & АНАЛИЗИРА & ВРЕДНУЈЕ & КРЕИРА \\
\hline $\begin{array}{c}\text { памти } \\
\text { претходно } \\
\text { научени } \\
\text { садржсај }\end{array}$ & $\begin{array}{l}\text { овладава } \\
\text { значењем } \\
\text { садржсаја }\end{array}$ & $\begin{array}{c}\text { користи } \\
\text { научено у } \\
\text { новим и } \\
\text { конкретним } \\
\text { ситуачијама }\end{array}$ & $\begin{array}{l}\text { разуме и } \\
\text { испитује } \\
\text { садржај }\end{array}$ & $\begin{array}{l}\text { просуһује о } \\
\text { вредности } \\
\text { садржаја }\end{array}$ & $\begin{array}{c}\text { формулише и } \\
\text { гради нове } \\
\text { структуре } \\
\text { од постојећих } \\
\text { садржсаја }\end{array}$ \\
\hline $\begin{array}{c}\text { дефинисати } \\
\text { указује } \\
\text { обележити } \\
\text { наводи/ } \\
\text { именује/ } \\
\text { набраја } \\
\text { при/сећа се } \\
\text { препознаје/ } \\
\text { идентификује } \\
\text { изјављује/ } \\
\text { изражава } \\
\text { репродукује... }\end{array}$ & $\begin{array}{c}\text { тумачи } \\
\text { прилагођава } \\
\text { асоцира } \\
\text { поентира } \\
\text { класификује } \\
\text { категорише } \\
\text { разликује } \\
\text { лоцира/ } \\
\text { означава/ } \\
\text { карактерише/ } \\
\text { одређује } \\
\text { описује } \\
\text { дискутује } \\
\text { објашњава } \\
\text { наводи } \\
\text { пример } \\
\text { парафразира } \\
\text { препознаје } \\
\text { формулише } \\
\text { разуме... }\end{array}$ & $\begin{array}{c}\text { формира } \\
\text { реализује/ } \\
\text { спроводи } \\
\text { управља } \\
\text { решава } \\
\text { прилагођава } \\
\text { саставља } \\
\text { комбинује } \\
\text { комуницира/ } \\
\text { размењује } \\
\text { приказује/ } \\
\text { демонстрира/ } \\
\text { симулира } \\
\text { открива/ } \\
\text { проналази } \\
\text { успоставља } \\
\text { излаже } \\
\text { утиче } \\
\text { илуструје } \\
\text { нстражује } \\
\text { прави } \\
\text { манипулише } \\
\text { организује } \\
\text { изводи/ } \\
\text { реализује } \\
\text { припрема/ } \\
\text { обезбеђује } \\
\text { вежбба } \\
\text { користи/ } \\
\text { примењује/ } \\
\text { ангажује... }\end{array}$ & $\begin{array}{c}\text { анлизира/ } \\
\text { разматра/ тумачи } \\
\text { одабира/ } \\
\text { селектује/ одваја } \\
\text { повезује } \\
\text { упоређује } \\
\text { експериментише } \\
\text { утврђује } \\
\text { испитује/ тестира } \\
\text { трага } \\
\text { преиспитује } \\
\text { супротставља } \\
\text { расчлањује } \\
\text { постав.ъа } \\
\text { мери } \\
\text { констатује } \\
\text { реконструише } \\
\text { консултује } \\
\text { поставља питања } \\
\text { систематизује... }\end{array}$ & $\begin{array}{c}\text { закључује } \\
\text { критикује } \\
\text { процењује } \\
\text { аргуменује/ } \\
\text { брани } \\
\text { вреднује/ } \\
\text { оцењује } \\
\text { резимира } \\
\text { просуђује } \\
\text { изводи } \\
\text { указује } \\
\text { верификује } \\
\text { / потврђује } \\
\text { предвиђа } \\
\text { одлучује... }\end{array}$ & $\begin{array}{c}\text { ствара/креира } \\
\text { продукује/ } \\
\text { производи } \\
\text { осмишљава } \\
\text { развија } \\
\text { мења } \\
\text { конструише } \\
\text { модисикује } \\
\text { довршава } \\
\text { побољшава/ } \\
\text { унапређује } \\
\text { прерађује... }\end{array}$ \\
\hline
\end{tabular}

Табела 1 Ревидирана Блумова таксономија глагола

\section{IV}

Један од важних аспеката, али и услова стваралачког процеса, поред искуства, јесу перцепција и доживљај, који су скоро у потпуности изостављени у Стандардима.

$$
\text { искуство + доживљај = стваралачки процес }
$$

Када се говори о искуству, оно може подразумевати и перцепцију, као вид чулног искуства. Ако изузмемо један од исхода у званичним Стандардима за напредни ниво који гласи ,уочавање међусобне повезаност елемената, принииа и садржаја на свом раду и на радовима других", на претходним нивоима у Стандардима скоро уопште се не предвиђају основне фазе перцепције као предуслов за „уочавање”, а то 
су посматрање, потом процес анализе чулних утисака и њихове прераде, а то је опажање/виђење, и на крају рецепција као прерађени чулни утисци, односно увиђање, уочавање.

Такође, доживљавање, односно активирање чулних утисака и покретање емоционалних процеса је један од услова за стваралачко изражавање, али ни оно није предвиђено исходима у званичним Стандардима. Запостављање значаја и функције доживљаја и емоционалног односа према различитим чулним и сазнајним елементима негирају стваралаштво у потпуности, и претварају уметност у бихејвиорални узрочно-последични однос онога што се очекује од ученика, и онога што ученик репродукује као готов, наводно, стваралачки продукт.

Узимајући у обзир да Блумова таксономија глагола покрива когнитивне аспекте знања, вештина и ставова, али не и перцептивни и емоционални аспект, који су саставни и неизоставни део стваралачког процеса, неопходно је дефинисати их кроз категорије и димензије перцептивних, емоционалних и креативних процеса на основу којих се могу одредити циљеви/исходи у домену стваралаштва. Препорука је да се исходи у стандардима ослањају, поред когнитивних процеca, и на 1. перцепцију (од опажања до мишљења), 2. доживљај и 3. креативност. Категорије које се односе на димензије перцептивних, доживљајних и креативних процеса које би требало узети у обзир при дефинисању исхода у домену ликовног стваралаштва су приказани у табели 2.

\begin{tabular}{|c|c|c|}
\hline & \multicolumn{2}{|c|}{$\begin{array}{l}\text { ДИМЕНЗИЈЕ ПЕРЦЕПТИВНИХ, ЕМОЦИОНАЛНИХ } \\
\text { ПРОЦЕСА У ДОМЕНУ ЛИКОВНОГ СТВАРАЛАШТВА }\end{array}$} \\
\hline \multirow{3}{*}{ 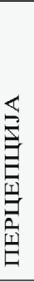 } & $\begin{array}{l}\text { 1. активирање сензорних } \\
\text { процеса }\end{array}$ & $\begin{array}{l}\text { - посматра } \\
\text { - додирује } \\
\text { - слуша } \\
\end{array}$ \\
\hline & $\begin{array}{l}\text { 2. опажање/ виђење као активно } \\
\text { истраживање, односно анализа, } \\
\text { прерада чулних утисака }\end{array}$ & $\begin{array}{l}\text { • опажа (види /сагледава / опсервира визуелно, } \\
\text { додиром и другим чулима) }\end{array}$ \\
\hline & $\begin{array}{l}\text { 3. рецепција као прерађени чулни } \\
\text { утисци (повезивање чулних } \\
\text { дражи у шире целине }\end{array}$ & - уочава / увића \\
\hline \multirow{3}{*}{ 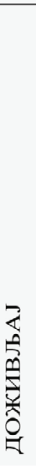 } & $\begin{array}{l}\text { 4. доживљај као процес синтезе } \\
\text { чулних надражаја, појмовних и } \\
\text { емоционалних искустава чија је } \\
\text { последица одређени ментални } \\
\text { процес - емоција, мишљење, } \\
\text { делање (доживљава на основу } \\
\text { стабилне перцепције као } \\
\text { психолошко прилагођавање } \\
\text { конкретној средини и као услов } \\
\text { за више менталне процесе - нпр. } \\
\text { визулно мишљење) }\end{array}$ & • доживљљава \\
\hline & $\begin{array}{l}\text { 5. рафинирана визуелна и } \\
\text { тактилна осетљивост }\end{array}$ & - показује сензитивност / сензибилност \\
\hline & $\begin{array}{l}\text { 6. изражавање осећања - } \\
\text { експресија-израз }\end{array}$ & $\begin{array}{l}\text { - објективно, видљиво изражава емоције } \\
\text { поредством различитих визуелних медија }\end{array}$ \\
\hline
\end{tabular}


САњА ФИЛИПОВИЋ

\begin{tabular}{|c|c|c|}
\hline \multirow{4}{*}{ 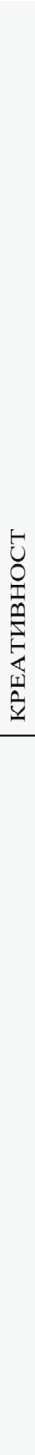 } & $\begin{array}{l}\text { 7. визуелно мишљење - } \\
\text { мишљење помоћу слика } \\
\text { (имагинација, фантазија, } \\
\text { замишљање): } \\
\text { мишљење засновано на основу } \\
\text { опажања и представама; } \\
\text { развијање визуелних представа, } \\
\text { симбола и њихова } \\
\text { трансформација; } \\
\text { развијање нових облика, са } \\
\text { новим значењима. }\end{array}$ & • Машта (замишља, фантазира) \\
\hline & $\begin{array}{l}\text { 8. дивергентно мишљење - } \\
\text { стварање нових идеја } \\
\text { а) флуентност/продуктивност } \\
\text { б) флексибилност } \\
\text { в) оригиналност } \\
\text { г) осетљивост на проблеме } \\
\text { д) елаборација } \\
\text { ђ) редефиниција } \\
\text { е) неукалупљеност } \\
\text { ж) проницљивост }\end{array}$ & $\begin{array}{l}\text { а) продукује велики број идеја, хипотеза и } \\
\text { изражајних средстава за решење једног } \\
\text { проблема; } \\
\text { б) брзо и лако прелази са идеје једног типа } \\
\text { мишљења на другу, удаљену од ње по својим } \\
\text { садржајима; брзо и успешно спаја и повезује } \\
\text { опажено са претходним искуствима; } \\
\text { в) долази до несвакидашњих, необичних или } \\
\text { потпуно нових идеја или опажања ствари у } \\
\text { новим односима, проналази ретка и } \\
\text { неуобичајена решења, одговоре, аналогије, везе } \\
\text { и метафоре које се разликују од стандардних и }\end{array}$ \\
\hline & & $\begin{array}{l}\text { општеприхваћених прилаза и поступака; } \\
\text { г) открива, увиђа проблем; } \\
\text { д) разрађује оригиналне идеје, организује } \\
\text { ликовни процес; } \\
\text { ђ) употребљава постојеће садржаје на нов } \\
\text { начин; } \\
\text { е) показује отвореност за нова искуства, идеје, } \\
\text { путеве трагања за решењима, прилази једном } \\
\text { проблему из више аспеката, лако напушта } \\
\text { уходане путеве, решава проблеме на нов } \\
\text { начин; } \\
\text { ж) успоставља нове односе и аналогије, } \\
\text { асоцијације и појмове који су међусобно } \\
\text { удаљени по значењу, комбинује и повезује } \\
\text { идеје у нову целину унутар широке скале } \\
\text { могућности и алтернатива. }\end{array}$ \\
\hline & $\begin{array}{l}\text { 9. Креативност/стваралаштво: } \\
\text { а) креативност спонтане } \\
\text { активности } \\
\text { б) креативност усмерене } \\
\text { активности } \\
\text { в) креативност инвенције } \\
\text { г) креативност иновације } \\
\text { д) креативност стварања }\end{array}$ & $\begin{array}{l}\text { а) изражава се самостално и спонатано; } \\
\text { б) спонтано се изражава уз свесно настојање за } \\
\text { побољшањем, постизањем сличности са } \\
\text { реалним објектом; } \\
\text { в) изражава нове ликовне односе; } \\
\text { г) уноси значајне промене у ликовном изразу } \\
\text { као што су сложеније ликовно-језичне и } \\
\text { техничке могућности; } \\
\text { д) ствара потпуно нове ликовно-појмовне } \\
\text { системе. }\end{array}$ \\
\hline
\end{tabular}

Табела 2 Категорије димензија перцептивних, доживљајних и креативних процеса

V

У наредном садржају дате су препоруке за дефинисање општих и специфичних циљева, као и исхода за крај обавезног образовања које би требало узети у обзир при ревидирању Образовних стандарда у области ликовне културе. Циљеви/исходи се одређују у складу са програмском концепцијом, садржајима као и развојним и индивидуалним могућностима ученика. У редефинисању општих и специфичних циљева ликовног васпитања и образовања, као и задатака 
наставника, треба поћи од савремених тенденција у домену педагогије, психологије и методике, програмском концепцијом наставе ликовне културе, садржајима, а на првом месту развојних и индивидуални могућности и потреба ученика. При одређивању циљева/исхода, потребно је јасно дефинисати и обухватити опште и специфичне појмове и њихово значење у домену ликовног васпитања и образовања. Један од репрезентативних модела је и Национални курикулум Велике Британије, ${ }^{4}$ где су појмови груписани и дефинисани на следећи начин: појмови који се односе на знања, вештине и способности, појмови који се односе на предмет и област проучавања и деловања и појмови који се односе на курикулум.

\section{Појмови који се односе на знања, вештине и способности}

Из појмова који се односе на ликовно васпитање и образовање произилазе и законитости стицања и проширивања знања, вештина и способности код ученика у процесу васпитно-образовног рада.

- Креативност и дивергентно мишьење као појмови у ужем смислу подразумевају да ученици показују креативност у игри медијима стварајући различите прилазе и одговоре на одређене задатке, на маштовит и лични начин како би стварали оригиналне ликовне радове. У конкретном раду креативност би значила да ученик продукује маштовите ликовне радове који су оригинални и вредни.

- Истраживање и експериментисање у ликовном раду подразумева истраживање и експериментисање идејама, материјалима, алаткама и техникама, при чему ученик у извесном смислу има свесну намеру и може да постави границе свог истраживања како би вредновало свој успех или неуспех, и у односу на то предузео следећи корак.

- Преузимање одговорности и учење на грешкама би значило да ученик треба да буде сигурно у преузимању ризика, трудећи се да уноси нове идеје и процесе без страха од грешке.

- Компетеничје подразумевају стицање вештина потребних у ликовном стваралаштву. Ученик треба да буде способан да примени ове вештине када истражује, анализира,

4 Nacional curriculum UK (2012) мрежна адреса документа (url): <http:// www.education.gov.uk/ и https://www.gov.uk/government/collections/national-curriculum- приступ 10.01.2014. 
размишља, ствара, дизајнира, изражава и вреднује, прави избор медија, техника и процеса рада.

- Анализирање представља кључни елемент практичних истраживања, развоја идеја и критичког мишљења. Доказ за анализу се може огледати у различитим видовима комуникације - дискусијама, кроз ликовно изражавање као и осталим формама комуникације.

- Дизајнирање укључује обликовање форми различитих сврха и намена и радну повезаност са праксом.

- Евалуачија или процеґивање представља континуиран процес и треба да укључује процену личних избора идеја, техника и материјала, напредовање ученика у раду и резултате које постиже.

- Медијуми подразумевају манипулисање класичним медијумима, као и новим технологијама.

- Разумевање културе подразумева способност да се истражује култура свог друштва и друштвене заједнице, групе у којима се учествује и питањима локалног и националног идентитета. Такође, подразумева комуникацију ученика са опсегом уметничких дела из различитих контекста, препознавање различитих карактеристика разних култура и коришћење истих као информација за сопствено креирање и стварање.

- Контекст или значење подразумева повезивање значења које се огледа у креативној и културној индустрији, као и разумевање улоге ликовних и примењених уметника и дизајнера у различитом опсегу култура, времена и значења.

- Критичко разумевање представља анализирање и критичку евалуацију као кључне аспекте креативног процеса. Ученици треба да развијају ове вештине у односу према свету који га окружује, његовом личном стваралаштву као и стваралаштву осталих. Такође критичко разумевање подразумева и истраживање визуелних, тактилних и осталих чулних опажања сопственог рада и радова других, комуникацију са идејама, уметничким делима и уочавање како су у њима саопштене вредности и значења.

- Развој сопствених погледа и изражавања рационалног и разложног просуђиваға подразумева развој и усвајање језика за изражавање мисли и идеја, изграђивање и вредновање ставова заснованих на постојећим вредностима или вредностима које сами креирају.

- Истраживање и креирање подразумева способност ученика да развија идеје и намере кроз разне облике 
опсервације, искуства, инспирације, имагинације и осталих извора. То може да укључује инспирисање радовима других, ликовно обликовање на основу сопственог искуства и на основу маште, као и реакције на стимулусе (подстицаје), или коришћење опажаја „на први поглед” да би се забележили доживљаји и идеје у визуелној и писаној форми. Такође ученик треба да буде оспособљен да истражује како да изрази и прави идеје користећи ликовне елементе и изражајне могућности медија, као и да ствара свесно ликовне радове, бирајући материјале, технике и процесе.

- Ликовно обликовање као проиес изражавања подразумева способност ученика да комуницира осећањима, искуствима и идејама, као и да се ликовно изражава. Ово може да укључује следеће: да ученик креира и открива (визуелизација, замишљање, машта); да опажа, истражује и проналази (свесно и са намером поступа, размишља и памти); да истражује идеје и могућности; да ствара из задовољства; да комуницира осећањима, идејама и искуствима са другима (визуелизација, коришћење знакова и симбола).

- Истраживачки рад и вештине подразумевају способност коришћења истраживачког рада и истраживачких вештина у ликовном стваралаштву (развијање идеје и намере када ствара ликовни рад), способност да се анализира, одабире и испитује критички, сумња и покрећу питања, да се праве разумни избори када се истражује лични рад. Такође се подразумева да се показује промишљено коришћење различитих извора, укључујући и сигуран интернет да би са намером пронашли информације развијајући при том аналитичке вештине и напредак у идејама, да се организује и презентује свој материјал и информације у подесним формама. Ученици би требало да буду способни у складу са узрастом да разумеју писане, визуелне и остале форме и комуницирају са окружењем.

- Еманципација и социјализаџија у контексту ликовног васпитања и образовања подразумевају осамостаљивање, укључивање у друштвени живот, уклапање у друштвену заједницу, процес прилагођавања ученика друштвеним нормама живота, морала и понашања, које се може огледати и кроз самосталност у стваралачком мишљењу и деловању.

- Емпатија, толеранција и хумани ставови се односе на развој способности саосећања са туђим мишљењем, осећањима, уживљавање у неки догађај или уметничко дело, затим уважавање права и прихватање различитости веровања, мишљења, обичаја других људи и заједница и поштовање људских права. 
- Култивисање ликовних способности подразумева оплемењивање и усавршавање ликовног језика које се огледа у способности стваралачког мишљења и деловања.

\section{Појмови који се односе на предмет и област проучавања и делована}

Појмови се односе на истраживање медија, процеса и техника у дводимензионалним, тродимензионалним и новим технологијама, као и на упознавање са опсегом уметничких дела кроз савремени, историјски и лични контекст и разумевање ликовних, примењених и дизајнерских техника и процеса.

- Ликовно укључује савремене и традиционалне, концепте, форме и медијуме изражавања кроз различите културе.

- Примењено се односи на продукте у уметности, занатима и дизајну који су онолико добри колико су радно повезани. Примери задатака радне повезаности укључују радну сарадњу на пројектима и преузимање улоге између дизајна и нивоа продукције. Ово може да укључује рад на пројектним задацима са коришћењем нових технологија које су заступљене у професионалном окружењу.

- Дводимензионално подразумева цртеже, слике, графике, фотографију, површинску декорацију и информатичкокомуникацијску технологију (ITC).

- Тродимензионално подразумева обликовање текстила, скулптуре, керамике, накита, сценских лутака и реквизита, инсталације и слично.

- Нове технологије укључују анимацију, филм, видео и веб дизајн.

- Учење опсега уметничких дела подразумева да ученици треба да се упознају са широким опсегом уметничких дела из националног и светског уметничког наслеђа, истражујући њихову функцију и везу са околином и потребама друштва.

\section{Појмови који се односе на курикулум}

Зависно од узраста курикулум треба да пружи различите могућности у односу на знања, вештине и способности, процесе и садржаје области ликовног васпитања и образовања.

- Радна сарадња укључује развој осетљивости и вештина потребних за закључивање, процењивање и учествовање у сарадничким процесима креирања и израде. Ученици могу да користе информатичко-комуникацијску технологију 
(ITC) тамо где су погодни, да истражују области које су нове за њих, укључујући идеје, технике и процесе, као и да реагују на школско окружење и локалне културне утицаје.

- Учествовање у ликовној уметности подразумева посете ликовних атељеа и студија, рад на различитим локацијама, посете уметницима, занатлијама и дизајнерима, искуство „учења на даљину” или „е-learning”, учење у виртуелном окружењу (интернет), учествовање у савременој уметности и дизајну, радећи са креативним појединцима и креативним окружењем (ово укључује искуство у истраживању свог рада кроз посету музејима и галеријама) колико је то могуће, као и да се изражавају у различитим ликовним подручјима укључујући истовремено вежбање.

- Мултидисииплинарност подразумева истраживање у интердисциплинарним и мултидисциплинарним вежбама унутар уметности, као што је комбиновање визуелних слика са звуком, говором, покретом и преношење на продукте стваралаштва.

На основу прегледа приказаних категорија и појмова, као и њиховог универзалног значења у контексту ликовног васпитања и образовања, као саставних елемената курикулума из области визуелних уметности, како у другим системима, тако и код нас, на основу компарације са исходима у Стандардима, може се уочити да велики број кључних појмова није обухваћен.

\section{Закључна разматрања}

Полазећи од основног значења и функције, циљеви представљају опредељења, намере и тежње које треба остварити у процесу ликовног васпитања и образовања, док исходи представљају оствареност резултата. Циљеви и исходи се разликују по својим основним функцијама. Циљеви омогућавају планирање и развој курикулума и обично су формулисани у облику глаголских именица, а исходи праћење и вредновање образовног процеса и формулисани су као активни глаголи, односно радње које ће ученици бити у стању да ураде по завршетку програма. Исходи би требало да имају следеће особине: да буду усклађени са развојним и индивидуалним карактеристикама ученика; да буду проверљиви (али нужно не и мерљиви); да буду позитивно формулисани, оствариви, комплексни и дељиви; да буду специфични (у смислу ко, шта, кад, где и како делује) и конкретни да омогуће адекватну организацију васпитно-образовног рада и проверу постигнућа, да буду прецизни, јасно формулисани да би се спречила различита тумачења. 
Ликовно васпитање и образовање, посебно настава ликовне културе у општем образовању, има првенствени задатак да допринесе перцептивно-моторном, социо-емоционалном, естетском, духовном и когнитивном развоју ученика, уз стицање одговарајућих искустава и сазнања из домена визуелне уметности, својеврсну прераду и процес изражавања. Одређивање циљева/исхода управо треба да обухвате све наведене аспекте, како би омогућили пуновредан развој и очување интегралности дечје личности. На основу анализе Стандарда и препорука датих у овом раду за њихово ревидирање, може се закључити следеће:

- Препорука је да се редефинишу три наведене области, а које се односе на медије, технике и материјале, на елементе, принципе, садржаје, као и визуелну уметност, и да се уведе као посебна, четврта област, а то је стваралачки процес, који се може сагледати кроз а) медији, технике и материјали - практична примена, садржаји -идеје и значења у односу на приказане теме и мотиве, б) ликовни језик - примена ликовних елемената и принципа компоновања и в) ликовни израз - периепиија, доживљај и креативност, из којих би били изведени исходи преко кључних компоненти учења;

- Да се јасније и прецизније дефинише појам „визуелна уметност" и подела уметничких грана, односно дисциплина унутар ње, а које се односе на кључне области 1. ликовну уметност (сликарство, графика и вајарство), 2. примењену уметност (примењено сликарство, примењено вајарство, конзервација и рестаурација уметничких дела, керамика, сценографија, костимографија, фотографија, илустрација...) и дизајн (графички дизајн, индустријски дизајн, дизајн ентеријера, модни дизајн, дизајн текстила, дизајн амбалаже...), укључујући и архитектуру. Такође, потребно је јасније одређење и категоризација медија као што су класични и нови медији који спадају у домен техника, материјала и начина њихове примене у визуелној уметности;

- Уочено је да су Стандардима обухваћене само три категорије когнитивних процеса које се односе на разумевање (разликује/лоцира, описује, препознаje), примену (изводи, користи) и анализу (анализира, одабира), док су памћење, вредновање и креирање потпуно изостављени. Полазећи од општих образовних и васпитних циљева, као и специфичних наставе ликовне културе, потребно је допунити опсег 
постојећих исхода у Стандардима у свим димензијама когнитивних процеса, посебно вредновања и креирања, и на тај начин проширити опсег ученичких компетенција уз уважавање њихових развојних могућности и индивидуалних потреба.

- Такође, доживљавање, односно активирање чулних утисака и покретање емоционалних процеса је један од услова за стваралачко изражавање, али ни оно није предвиђено исходима у званичним Стандардима. Запостављање значаја и функције доживљаја и емоционалног односа према различитим чулним и сазнајним елементима негирају стваралаштво у потпуности. Узимајући у обзир да Блумова таксономија глагола покрива когнитивне аспекте знања, вештина и ставова, али не и перцептивни и емоционални аспект, који су саставни и неизоставни део стваралачког процеса, неопходно је дефинисати их кроз категорије и димензије перцептивних, емоционалних и креативних процеса на основу којих се могу одредити циљеви/исходи у домену стваралаштва. Препорука је да се исходи у стандардима ослањају, поред когнитивних процеса, и на 1. перцепцију (од опажања до мишљења), 2. доживљај и 3. креативност. Категорије које се односе на димензије перцептивних, доживљајних и креативних процеса које би требало узети у обзир при дефинисању исхода предложени су у овом раду.

- Редефинисати опште и специфичне циљеве, као и исходе за крај обавезног образовања у настави ликовне културе које би требало узети у обзир при ревидирању Образовних стандарда у овој области. У редефинисању општих и специфичних циљева ликовног васпитања и образовања, као и задатака наставника, треба поћи од савремених тенденција у домену педагогије, психологије и методике, програмске концепције наставе ликовне културе, садржаја, а на првом месту развојних и индивидуалних могућности и потреба ученика. При одређивању циљева/исхода, потребно је јасно дефинисати и обухватити опште и специфичне појмове и њихово значење у домену ликовног васпитања и образовања а који се односе на знана, вештине и способности, на предмет и област проучавања и деловања и на курикулум.

На крају, треба рећи да нема објективно исправне уметности, као ни правила за уметнички успех, јер правила која су људи створили се константно мењају, а њен значај и функција јесте да представља рефлексију индивидуалног 
стварања у уметности. Смисао, значај и функција ликовног васпитања и образовања јесте у постепеном увођењу ученика у ликовну културу, зависно од њиховог узраста, потреба и индивидуалних могућности, омогућавајући им да кроз ликовно стваралаштво изражавају себе и комуницирају са окружењем. „Ликовна уметност може да обезбеди шансу за раст неколико виталних подручја - перцептуални раст кроз сва чула, креативни развој кроз флексибилност, машту, оригиналност, флуентност у мишљењу, емоционални раст, односно способност да се ученик суочи са новим ситуацијама, као и да изрази лепа или ружна осећања, интелектуални, друштвени и естетски развој. Такође ликовно стваралаштво треба да обезбеди шансу да ученик истражује, прави грешке, опробава, има осећај страха или мржње, љубави или радости. Најважније је да треба да има сва ова животна искуства за себе као јединку, индивидуу која може, треба и мислиће за себе."

\section{ЛИТЕРАТУРА:}

Anderson, L. W., Krathwohl, D. R., Airasian, P. W., Cruikshank, K. A., Mayer, R. E., Pintrich, P. R., Raths, J., and Wittrock, M. C. (2001) A taxonomy for learning, teaching, and assessing: A revision of Bloom's Taxonomy of Educational Objectives (Complete edition), Longman: New York.

Арнхајм, Р. (1985) Визуелно мишљење, Универзитет уметности, Београд.

Панић, В. (1998) Речник психологије стваралаштва, ЗЗУНС: Београд.

Guilford, J. P. (1957) Creative abilities in the arts. Psychological Review, Vol 64(2), p. 110-118; мрежна адреса документа (url): http:// psycnet.apa.org/journals/rev/64/2/110/ приступ 27.01.2014.>

Каменов, Е. (1997) Методика 1, 2 и 3, Одсек за педагогију Филозофског факултета у Новом Саду и Републичка Заједница виших школа за образовање васпитача: Београд.

Lowenfeld, V. and Brittain, W. L. (1975) Creative and mental growth, New York: Macmillan Publishing Co. Inc.

Nacional curriculum UK (2012). мрежна адреса документа (url): $<$ http://www.education.gov.uk/ и https://www.gov.uk/government/collections/national-curriculum- приступ 10.01.2014.>

Образовни стандарди за крај обавезног образоваға (2009). Завод за вредновање квалитета образовања и васпитања Република Србија. мрежна адреса документа (url): <http://www.ceo.edu.rs/portal/ - приступ 10.01.2014.>

Трој, Ф. (1972) Психологија детета, Београд: Научна књига

5 Lowenfeld, V. and Brittain, W. L. (1975) Creative and mental growth, New York: Macmillan Publishing Co., Inc, p. 182. 
САЊА ФИЛИПОВИЋ

Sanja Filipović

University of Arts, Faculty of Fine Arts, Belgrade

\title{
OFFICIAL EDUCATIONAL STANDARDS IN THE FIELD OF VISUAL CULTURE AT THE END OF COMPULSORY EDUCATION - HOW TO OVERCOME DEFECTS
}

\begin{abstract}
Considering general principles of fostering creativity in children and youngsters together with empirically proven knowledge of numerous experts and the tendency of modern teaching methods in the field of creativity, it becomes clear that the range of knowledge, skills and attitudes in art education provided by the Educational standards for the end of compulsory education in Serbia is incomplete and unsystematic. The current conception of Standards in the field of visual arts is completely pointless due to the omission of the aspect of creativity. The consequences of the issues established in the Current conception of standards in the field of visual arts are harmful not only for the development of children's creativity, but also for the development of the entire personality. In this way the basic human, above all children's right and need for creative expression and action is formally disabled. Also, performing of the key objectives in art education, especially teaching art is disabled. The key objectives are just formally represented in some issues within Standards without possibility of their systematical realization within the current educational practice.
\end{abstract}

Key words: Standards in education, teaching art, children's artistic creativity

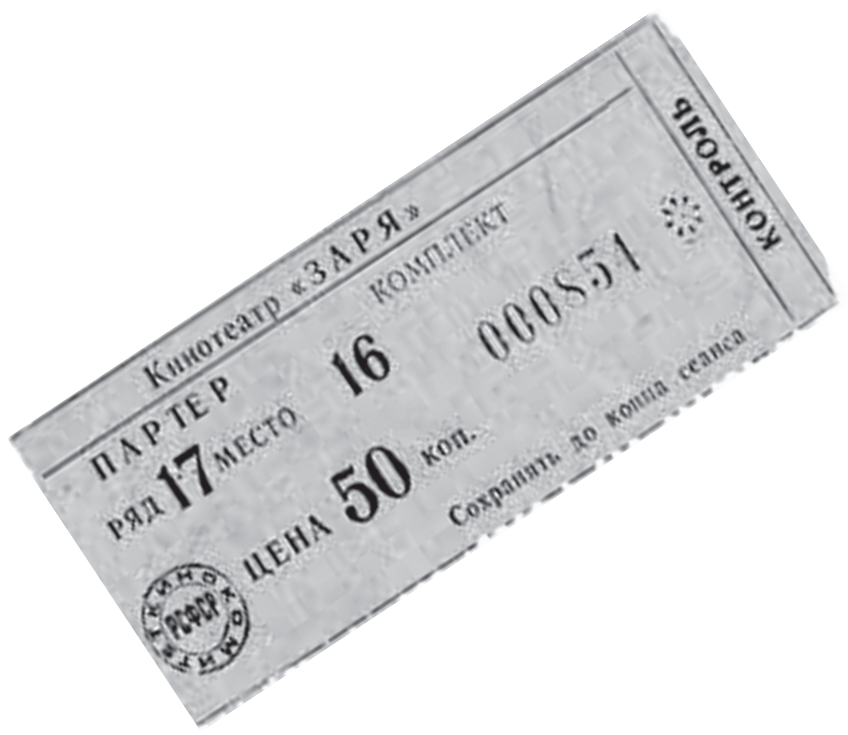

